\title{
First record of Hemidiaptomus (Gigantodiaptomus) superbus (Schmeil, 1895) in Italy, with notes on distribution and conservation status (Copepoda, Calanoida, Diaptomidae)
}

\author{
Federico MARRONE*, Giuseppe ALFONSO ${ }^{1)}$, Danio MISEROCCHI ${ }^{2)}$ and Sabrina LO BRUTTO \\ Department of Animal Biology "G. Reverberi", University of Palermo, Via Archirafi 18, 90123 Palermo, Italy \\ ${ }^{1)}$ Laboratory of Zoogeography and Fauna, Department of Biological and Environmental Sciences and Technologies (Di.S.Te.B.A.), \\ University of Salento, 73100 Lecce, Italy \\ ${ }^{2)}$ Museo Civico di Storia Naturale di Ferrara, Via De Pisis 24, 44121 Ferrara, Italy \\ *e-mail corresponding author: federico.marrone@neomedia.it
}

\begin{abstract}
Hemidiaptomus (Gigantodiaptomus) superbus (Schmeil, 1895) was found in a temporary pool in the Pineta di Classe coastal pine-wood (Ravenna, northern Italy). This is the first official record of a species belonging to the subgenus Gigantodiaptomus of Italian fauna, and it widens the known distribution of this rare diaptomid to the Mediterranean basin. In order to supply data on this rare and poorly known species, original drawings for the Italian population have been provided, and some overlooked morphological features have been highlighted. In light of the growing evidence of the existence of a number of cryptic species in the Diaptomidae family, and considering the variability observed in the ornamentation of the fifth pair of female legs, the ribosomal DNA marker $16 S$ was used to compare the specimens collected in Italy with those from the terra typica of the species. Molecular data confirmed the strict conspecificity of the two populations being studied. The environmental parameters relating to the new Italian site are described and compared with the few data currently available in the literature. A careful review of all the published data dealing with $\mathrm{H}$. (G.) superbus has been performed, and the paucity of recent records is stressed, together with the opportunity to support dedicated conservation measures for the protection of this species.
\end{abstract}

Key words: temporary ponds, zooplankton, biogeography, biodiversity, $16 S$ rDNA

\section{INTRODUCTION}

The Palaearctic diaptomid genus Hemidiaptomus Sars 1903 includes 19 species, occurring in temporary water bodies from Mongolia to Spain and Morocco (Dussart \& Defaye 2002; Stepanova 2005a). These species are currently divided into three subgenera, i.e. Hemidiaptomus s. str. Sars 1903, Gigantodiaptomus Kiefer 1932, and Occidodiaptomus Borutzky 1991, all of which are mostly parapatric and present in limited co-occurrence areas (Kiefer 1978; Dussart \& Defaye 2002; Marrone et al. 2010). The subgenus Gigantodiaptomus, a taxon considered of genus rank by some authors (Stepanova 2005b; Walter 2010), includes five species occurring in Asia and central Europe. Of these, Hemidiaptomus (Gigantodiaptomus) superbus (Schmeil 1895) has proved to be the rarest and most enigmatic species of the group. In spite of its widespread distribution, which covers central/eastern Europe and the Caucasus, few records are currently available and most of these are old reports lacking iconography and in need of confirmation.

Hemidiaptomus $(G$.) superbus has been described by Schmeil (1895) as 'Diaptomus' superbus, based on specimens collected from temporary ponds in the 'Biederitzer Busch bei Magdeburg' (Germany) and the draw- ings published one year later (Schmeil 1896). Kiefer (1932a, 1932b) transposed it to the subgenus Gigantodiaptomus of the genus Hemidiaptomus, whilst stressing peculiarities of $H$. (G.) superbus, which are not typical of the other species of that subgenus. This attribution is nowadays widely accepted (e.g., Dussart \& Defaye 2002) with the only exception of Einsle (1993), who has assigned the species to the subgenus Hemidiaptomus $\mathrm{s}$. str., and Stepanova (2005a), who has raised the subgenus Gigantodiaptomus to genus level.

Its description having been documented, the species was sighted in Denmark (Jensen 1905 in: Tollinger 1911), the Ukraine (Belousov, 1908), France (Beuchamp 1918), Algeria (Roy 1924), Croatia and Serbia (Krmpotić 1925; Ternjej \& Stankovic 2007; I. Ternjej, pers. comm.), Azerbaijan (Weisig 1931), Germany (Elster 1931, Gillandt \& Martens, 1975; Gillandt et al. 1983), Iran (Brehm 1937), and Poland (Błędzki 2008) (Fig. 1). Based on the absence of setae on the distal part of the endopodites of the fifth pair of female legs, the $H$. (G.) superbus populations found in the Caucasus were considered by Brehm (1937) as a different variety of the European H.(G.) superbus, and the author gave it the name of 'Hemidiaptomus superbus var. hyrcanensis'. This taxon, accepted by Löffler (1961) and Kiefer (1978), was later synonymised with $H$. (G.) superbus by Dussart \& Defaye (2002). 


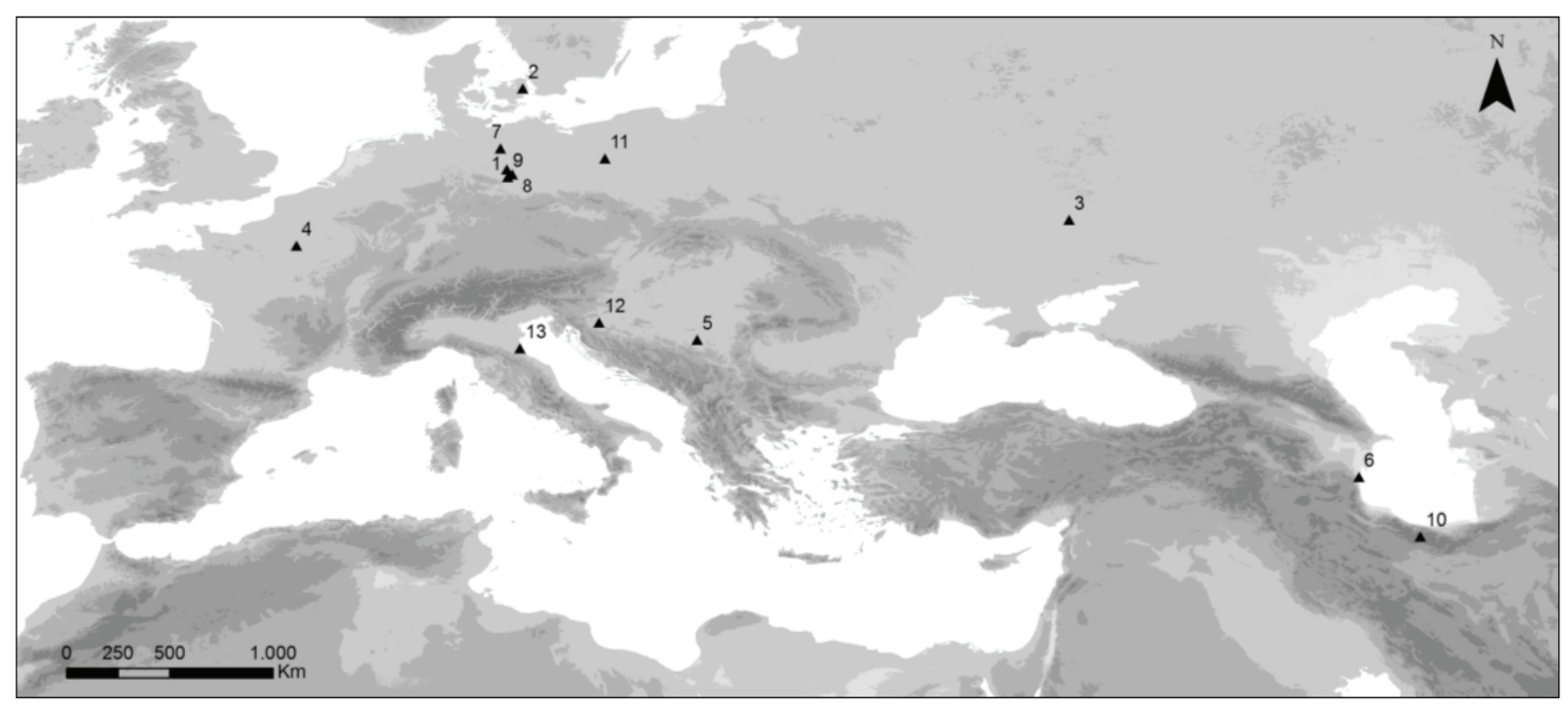

Fig. 1. Occurrence localities of $H$. (G.) superbus. Sources: 1: Schmeil, 1895; 2: Jensen, 1905; 3: Belousov, 1908; 4: Beuchamp, 1918; 5: Krmpotić, 1925; 6: Weisig, 1931; 7: Gillandt \& Martens, 1975; 8, 9: Elster, 1931; 10: Brehm, 1937; 11: Błędzki, 2008; 12: I. Ternjej, pers. com.; 13: Present work. The record of the species for Algeria (Roy, 1924) is most likely erroneous (see text) and thus has not been reported on the map.

Unfortunately, most of the reports of the species were published without drawings, which precludes checks as to their reliability e.g., Hemidiaptomus (G.) superbus was officially recorded in the Reghaïa forest, near Algiers (Roy, 1924), a site where extensive surveys carried out in subsequent years led to the finding of the only Hemidiaptomus (Occidodiaptomus) ingens (Gauthier 1928). Furthermore, Roy \& Gauthier (1927) did not include $H$. (G.) superbus in their work on the copepod fauna of Algeria, thus implying that the authors themselves deemed that the previous record of the species in Algeria was erroneous. Currently, reports of the species are considered doubtful (Dussart 1989), or have not been reported at all (Mouelhi et al. 2000; Hamaidi et al. 2010) in the Reviews dealing with the copepods of Algeria and the Maghreb.

Given the unreliability of some of the older records, all those relating to Hemidiaptomus (G.) superbus, which lack adequate iconography, should be confirmed. Thus, the presence of the species can only be considered certain for Germany (Schmeil 1895; Elster 1931, Gillandt \& Martens 1975; Gillandt et al. 1983) and the southern coast of the Caspian Sea (Azerbaijan and Iran) (Weisig 1931; Brehm 1937; Löffler 1961). No record of the species has been published for the last seventy years, with the exception of a single population from Peverstof, Germany (Gillandt \& Martens 1975; Gillandt et al. 1983). H. (G.) superbus is currently unanimously considered as one of the rarest Palaearctic diaptomid species (Dussart 1967, 1989; Kiefer 1978; Einsle 1993). By means of an extensive faunal survey, the aim of which was to update the checklist and distribution of Italian inland water copepods, various specimens of $H$. (G.) superbus were collected in a temporary pool near Ravenna (northern Italy).

\section{MATERIALS AND METHODS}

The study material was collected on 6 June 2010 in four temporary pools in the Pineta di Classe near Ravenna, Italy. The sampled sites are shallow, clearwater temporary pools, which are located in a mature coastal pinewood. The bioclimatic characterization of the area is based on the classification formulated by Rivas-Martinez (1995). Water temperature, $\mathrm{pH}$ and specific conductivity were registered with a MM40 Crison multimeter. Microcrustacean samples were collected by means of a $200 \mu \mathrm{m}$ mesh-sized hand net and fixed in situ with $80 \%$ ethanol. Calanoid copepods were isolated, dissected under the stereomicroscope and identified to the species level, according to Kiefer (1978), Borutzky et al. (1991) and Einsle (1993). Co-occurring Cladocera, Cyclopoida, and Ostracoda were identified according to Margaritora (1985), Alonso (1996), Meisch (2000), Einsle (1993), as updated following the recent literature. Drawings of selected specimens (total length, females: $4200 \mu \mathrm{m}$; males: $3400 \mu \mathrm{m}$ ) were made with a Zeiss $^{\circledR}$ Standard 18 compound microscope, which is equipped with a camera lucida, after tissue cleaning with in hot lactic acid. Preserved specimens and mounted slides have been stored in the authors' collection.

Various specimens of Hemidiaptomus (G.) superbus and environmental data from a temporary pond near the town of Breitenhagen (Germany) have been included in the study as comparative material. This site (coordinates UTM-WGS84 32U: 5756674 N; 703109 E; Altitude: 53 m a.s.1.) was sampled on 4 April 2008, its location being the same river basin of the type locality of the species (i.e., the Elbe River basin), and approximately $30 \mathrm{~km}$ from its locus typicus. The site was rich in water 
macrophytes, water temperature was $12.1^{\circ} \mathrm{C}$, and specific conductivity was $1430 \mu \mathrm{S} \mathrm{cm} \mathrm{cm}^{-1}$ on the sampling date. Adult specimens of Hemidiaptomus (G.) superbus and Hemidiaptomus (G.) amblyodon (Marenzeller 1837) specimens were collected at the same time.

In light of the growing evidence of the presence of a cryptic species among diaptomid calanoid copepods (e.g., Thum \& Harrison 2009) and within the genus Hemidiaptomus in particular (Marrone et al. 2010) and in order to check for the molecular divergence between the populations being studied, a fragment of the $16 \mathrm{~S}$ ribosomal mtDNA was amplified from a single $H$. (G.) superbus specimen per population. Prior to DNA extraction, specimens were carefully cleaned and soaked in double-distilled water for 3 hours. DNA was then extracted using whole specimens and the "DNEasy Animal Tissue Kit" (QIAGEN). A partial sequence of the $16 \mathrm{~S}$ ribosomal DNA subunit was then amplified using the "Skisto-1" (5' -TGG TAA GGT AGC ATA ATA AT- 3') e Skisto-2 (5'- CCG GTT TGA ACT CAG ATC ATG T -3') primers, as described by Thum \& Harrison (2009).

The PCR mix consisted of $3.5 \mu$ of Buffer $10 \times$ (THERMOSCIENTIFIC), $3 \mu \mathrm{L}$ of $25 \mathrm{mM} \mathrm{MgCl}_{2}, 0.35$ $\mu \mathrm{L}$ of dNTP $10 \mathrm{mM}, 1 \mu \mathrm{L}$ of each $10 \mu \mathrm{M}$ primer, $0.4 \mu \mathrm{L}$ of Red Hot Taq Polymerase 5U/ $\mu \mathrm{L}$ (THERMOSCIENTIFIC), $1 \mu \mathrm{L}$ of DNA template, and $23.7 \mu \mathrm{L}$ of double-distilled water, producing a total reaction volume of $35 \mu \mathrm{L}$. The amplification consisted of an initial denaturation step of $94{ }^{\circ} \mathrm{C}$ for 4 minutes, followed by 35 cycles of $94{ }^{\circ} \mathrm{C}$ for 50 seconds, $42{ }^{\circ} \mathrm{C}$ for 50 seconds, and $72{ }^{\circ} \mathrm{C}$ for 1 minute, followed by a final extension at $72{ }^{\circ} \mathrm{C}$ for 8 minutes. The PCR products were separated by electrophoresis on $2 \%$ agarose gel at $70 \mathrm{~V}$ for $1 \mathrm{~h}$ and visualized with a UV Transilluminator. Amplified bands were cut, purified from agarose gel (using the Qiaquick Gel Extraction Kit) (QIAGEN) and sequenced in forward and reverse directions with a ROCHE GENOME SEQUENCER FLX. Chromatograms were imported and edited with Chromas Lite 2.01 (TECHNELYSIUM PTY LTD) and exported to be aligned with BioEdit (Hall 1999); sequence divergence was calculated with Mega ver. 4 (Tamura et al. 2007). The sequences have been deposited in GenBank (Accession numbers: HQ687215 and HQ687216).

\section{RESULTS AND DISCUSSION}

A population of Hemidiaptomus (G.) superbus has been located in Italy approximately three decades after the last published record of the species (Gillandt et al. 1983). The morphology of the Italian specimens correlates well with the description of the species currently available in the literature (Kiefer 1978; Borutzky et al. 1991; Einsle 1993). However, the presence of a small chitinous hump on the dorsal side of the second segment of the exopodite of fifth, right, male leg (Fig. 2H), which was present in all the studied male specimens, has not to date been reported in the published drawings. Within the Gigantodiaptomus subgenus, this chitinous outgrowth is reported to occur in all the species with the only exception of $H$. (G.) hungaricus (Kiefer 1978; Stepanova 2005a).

Furthermore, the length of the apical setae on the endopodite of fifth female pair of legs (Fig. 2B) is slightly shorter than that reported in the available drawings of German specimens (Gillandt \& Martens 1975; Kiefer 1978; Einsle 1993). This characteristic is noteworthy as the 'hyrcanensis' variety of $H$. (G.) superbus was described as lacking these setae in the specimens originating from the Caucasus (Brehm 1937). It thus seems that a certain variability exists in the ornamentation of the fifth pair of female legs, which also concerns the presence of a trasversal row of spinules on the apical part of the second exopodal segment of the fifth leg: these spinules are present in the German and Italian specimens (e.g., Fig. 2B) but they are absent in the specimens from the Balkans (Krmpotić 1925).

A 350 base-pairs long fragment of the ribosomal DNA subunit $16 \mathrm{~S}$ was successfully amplified and sequenced. The uncorrected p-distance between the amplified sequences is just $0.9 \%$ (Fig. 3), while it often accounts for $14.9-23 \%$ among congeneric diaptomid species and even among distinct presumed intraspecific clades (Thum \& Harrison 2009). Thus, molecular data confirm the conspecificity of the two populations under study and the existence of a certain intraspecific variability in the ornamentation of the fifth pair of female legs.

The co-occurring microcrustacean fauna, collected in the Pineta di Classe pools (Tab. 1), consists of species which are widespread in Italy and often related to slightly brackish water bodies (Marrone et al. 2006a; Stoch 2006; pers. obs. of the authors). Hemidiaptomus (G.) superbus was collected in only one out of the four sampled sites (i.e. 'pool A') on the sampling date but large diaptomids, probably $H$. (G.) superbus, had also been observed in the other pools in May 2010 (D. Miserocchi, personal observation). Coordinates, water temperature, $\mathrm{pH}$ and the specific conductivity of the sampled pools are reported in table 2 . The pools were a few square metres in width on the sampling date and the only observed macrophytes were Alisma lanceolata With. and Galium palustre L.

According to Rivas-Martinez (1995), both the Italian and the German areas, where $H$. (G.) superbus occur, lie in the temperate-oceanic bioclimatic area. However, all the other Hemidiaptomus species occurring in Italy, i.e. Hemidiaptomus (Hemidiaptomus) gurneyi, H. (Occidodiaptomus) ingens s.l., and $H$. (O.) roubaui (Ruffo \& Stoch 2006; Marrone et al. 2006b; Marrone et al. 2010; Alfonso \& Belmonte 2011) occur in areas characterised by a Mediterranean pluviseasonal, oceanic bioclimate. Unfortunately, the scarce and anecdotal data currently available for Hemidiaptomus (G.) superbus do not clarify the ecological preferences of the species. 


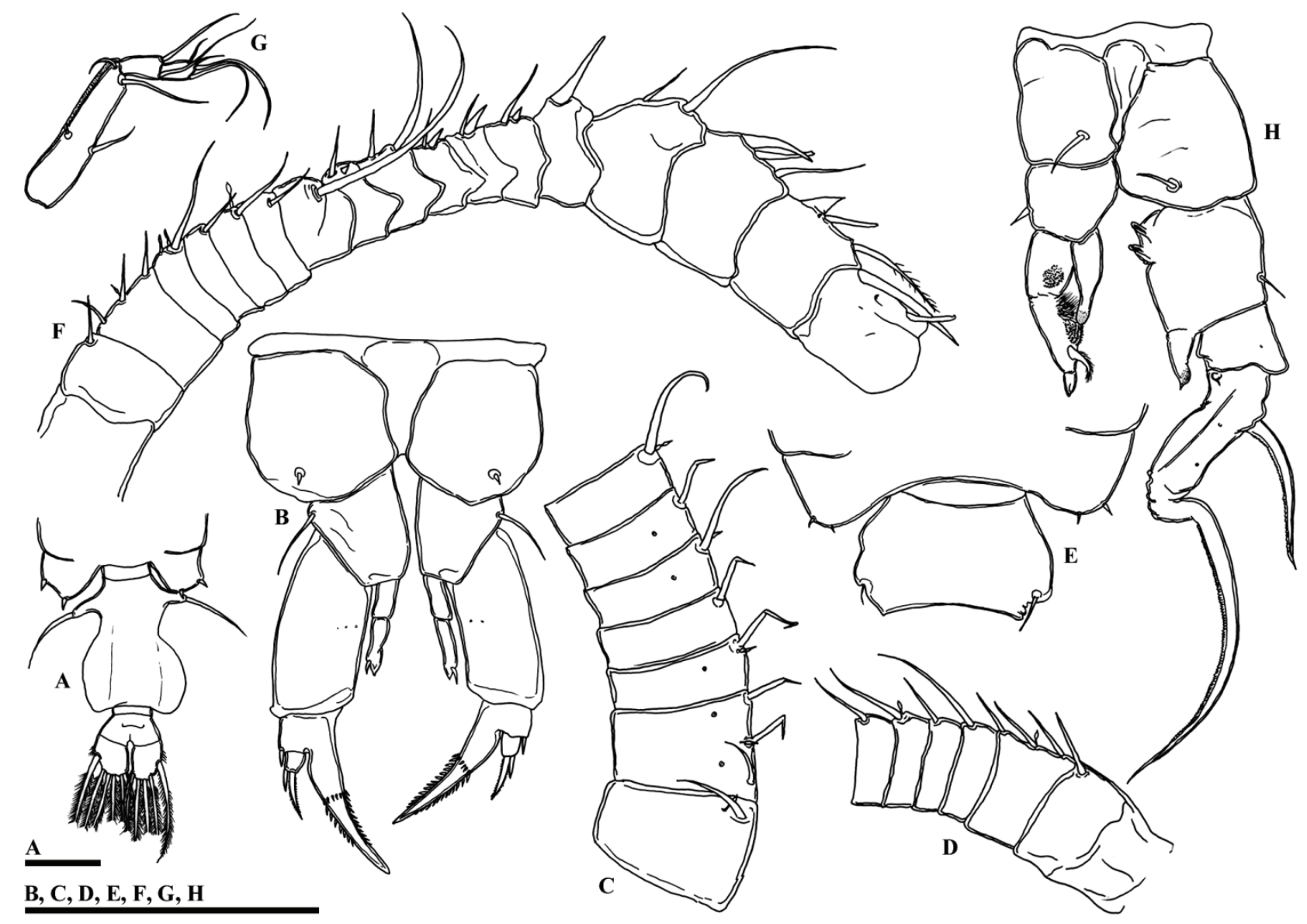

Fig. 2. A-C: Hemidiaptomus superbus, female. A: somites 4-5 and urosome; B: fifth pair of legs; C: antennula, segments 1-7. D-H: H. superbus, male. D: left antennula, segments 1-6; E: somite 5 and genital segment; F: right antennula, segments 1-17; G: right antennula, last three segments; H: fifth pair of legs. Scale bars: $500 \mu \mathrm{m}$.

Tab. 1. List of crustaceans occurring in the sampled pools on 6 June 2010.

\begin{tabular}{|c|c|c|c|c|}
\hline Taxa & $\begin{array}{l}\text { Pool A } \\
\text { ER003 }\end{array}$ & $\begin{array}{l}\text { Pool B } \\
\text { ER004 }\end{array}$ & $\begin{array}{l}\text { Pool C } \\
\text { ER005 }\end{array}$ & $\begin{array}{l}\text { Pool D } \\
\text { ER006 }\end{array}$ \\
\hline $\begin{array}{l}\text { Copepoda } \\
\text { Calanoida } \\
\text { Diaptomidae }\end{array}$ & & & & \\
\hline $\begin{array}{l}\text { Hemidiaptomus (Gigantodiaptomus) superbus (Schmeil, 1895) } \\
\text { Mixodiaptomus kupelwieseri (Brehm, 1907) }\end{array}$ & $\begin{array}{l}X \\
X\end{array}$ & $X$ & $X$ & $X$ \\
\hline $\begin{array}{l}\text { Copepoda } \\
\text { Cyclopoida }\end{array}$ & & & & \\
\hline $\begin{array}{l}\text { Cyclops divergens (Lindberg, 1936) } \\
\text { Megacyclops viridis (Jurine, 1820) } \\
\text { Diacyclops bisetosus (Rehberg, 1880) } \\
\text { Diacyclops lubbocki (Brady, 1869) }\end{array}$ & $\begin{array}{l}X \\
X \\
X \\
X\end{array}$ & $\begin{array}{l}X \\
X \\
X \\
X\end{array}$ & $\mathrm{X}$ & $\begin{array}{l}X \\
X \\
X\end{array}$ \\
\hline $\begin{array}{l}\text { Branchiopoda } \\
\text { Anomopoda } \\
\text { Daphniidae }\end{array}$ & & & & \\
\hline $\begin{array}{l}\text { Scapholeberis rammneri (Dumont \& Pensaert, 1983) } \\
\text { Ceriodaphnia laticaudata (P.E. Müller, 1867) } \\
\text { Daphnia (Daphnia) curvirostris (Eylmann, 1887) }\end{array}$ & & $\begin{array}{l}X \\
X \\
X\end{array}$ & $\begin{array}{l}X \\
X\end{array}$ & $X$ \\
\hline $\begin{array}{l}\text { Ostracoda } \\
\quad \text { Podocopa } \\
\quad \text { Candonidae } \\
\text { Unidentified larvae }\end{array}$ & & & $X$ & \\
\hline $\begin{array}{l}\quad \text { Cyprididae } \\
\text { Eucypris virens 'complex' (Jurine, 1820) } \\
\text { Heterocypris salina (Brady, 1868) }\end{array}$ & $X$ & $X$ & $X$ & $X$ \\
\hline
\end{tabular}




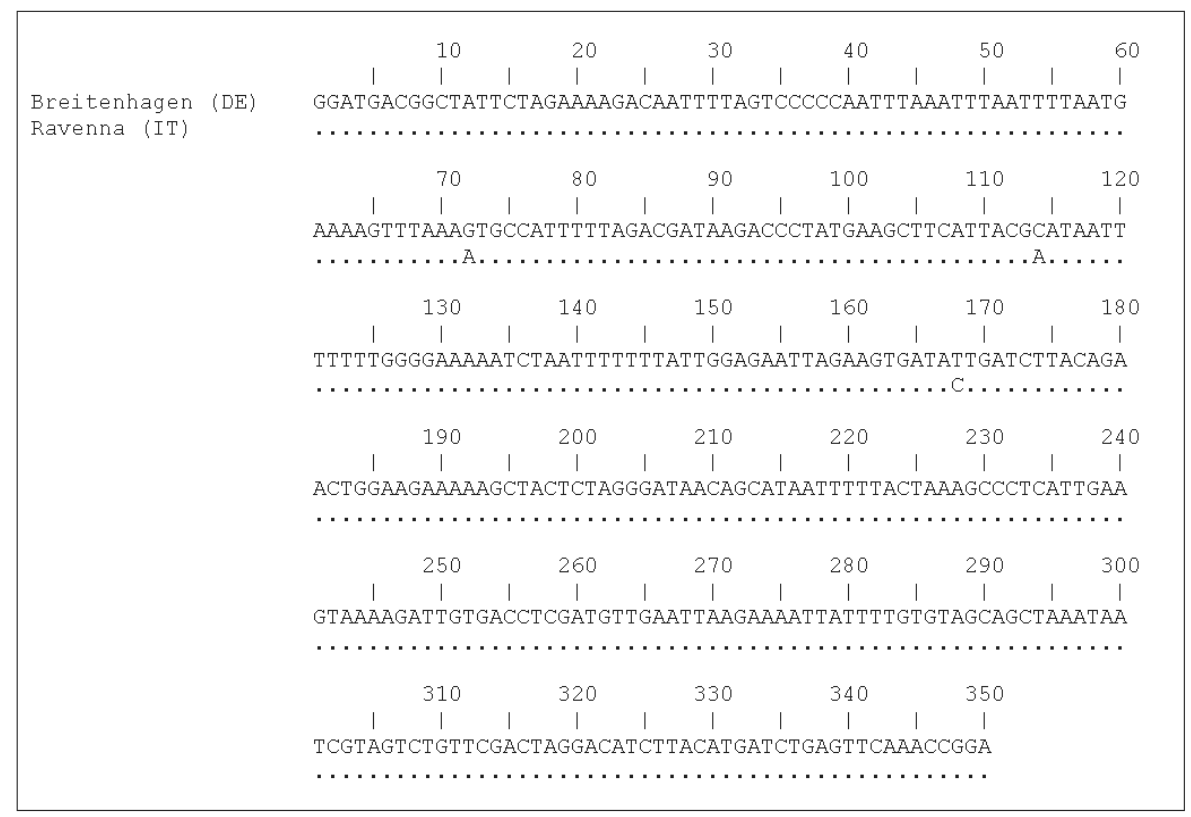

Fig. 3. Compared 16S rDNA nucleotide sequences for the Pineta di Classe (Ravenna, Italy) and Breitenhagen (Salzlandkreis, Germany) populations.

Tab. 2. Coordinates, water temperature, $\mathrm{pH}$ and water conductivity of the sampled pools on 6 June 2010.

\begin{tabular}{lcccc}
\hline & $\begin{array}{c}\text { Coordinates } \\
(\mathrm{UTM}-W \mathrm{~N} 84)\end{array}$ & $\begin{array}{c}\text { Water Temperature } \\
\left({ }^{\circ} \mathrm{C}\right)\end{array}$ & $\begin{array}{c}\text { Specific conductivity } \\
\left.(\mu \mathrm{S} \mathrm{cm})^{-1}\right)\end{array}$ & $\mathrm{pH}$ \\
\hline Pool A - ER003 & $4913408 \mathrm{~N} ; 33283404 \mathrm{E}$ & 24 & 1433 & 8.04 \\
Pool B - ER004 & $4913413 \mathrm{~N} ; 33283411 \mathrm{E}$ & 25 & 864 & 7.89 \\
Pool C - ER005 & $4913411 \mathrm{~N} ; 33283426 \mathrm{E}$ & 25.2 & 1329 & 7.94 \\
Pool D - ER006 & $4913418 \mathrm{~N} ; 33283442 \mathrm{E}$ & 24.1 & 768 & 7.95 \\
\hline
\end{tabular}

However, a rather high degree of specific conductivity was recorded for both the Italian and German sites, which is quite unusual for most Hemidiaptomus species (e.g., Gauthier 1928; Alonso 1998; Marrone et al. 2006a).

The scattered geographical and temporal distribution of the records of occurrence of $H$. (G.) superbus might be ascribed to three different reasons, which are not mutually exclusive: (i) the species could be naturally rare in nature; (ii) the distribution barycentre of $H$. (G.) superbus might indeed occur in relatively unknown regions of south-eastern Europe and the Caucasus, thus being present in western Europe only with few, shortliving populations which episodically colonise sites along the westernmost fringe of the species' distribution area; and (iii) the species could have experienced a total collapse in recent decades, having been replaced by other, more generalist, copepod species. The latter hypothesis is supported by the fact that, compared to nine records published between 1895 and 1937 (Schmeil 1895; Jensen 1905; Belousov 1908; Beauchamp 1918; Roy 1924; Krmpotić 1925; Weisig 1931; Elster 1931; Brehm 1937), only two records of Hemidiaptomus (G.) superbus were published after 1895 and both of them regarded the same area near the town of Pevestorf, Germany (Gillandt \& Martens 1975;
Gillandt et al. 1983). The occurrence of the species near Breitenhagen (Germany), which was reported by Elster (1931), has been confirmed in the ambit of this study; however, it was not possible to find $H$. (G.) superbus in the locus typicus of the species (Schmeil, 1895) in the Magdeburg area, which is the other site reported by the same author (Elster 1931). Furthermore, the European distribution area of $H$. (G.) superbus overlaps with that of the more common and widespread congeneric species Hemidiaptomus (G.) amblyodon (Dussart \& Defaye 2002), which could have replaced the $H$. (G.) superbus in various sites. This process might be ongoing, e.g. these two Hemidiaptomus species currently co-occur in the Breitenhagen pond, both syntopically and synchronically, while Elster (1931) reported for the same site the occurrence of $H$. (G.) superbus only.

It is necessary to confirm the current presence of the species for most of the countries where it has been recorded, and it would be desirable to check the historical and current occurrence of $H$. (G.) superbus throughout its known distribution area. Until more data regarding the distribution and consistency of the species in Europe are available, dedicated, protective measures of the few, confirmed known occurrence sites of the species (i.e., the pools in the Pineta di Classe in Italy, and the ponds near Breitenhagen and Pevestorf in Germany) 
should be implemented, and $H$. (G.) superbus should be included on the national 'red lists' for invertebrates (e.g., Herbst 1982).

The presence of Hemidiaptomus (Gigantodiaptomus) superbus in Italy, which constitutes the first Hemidiaptomus record from the Padanian faunal province (Minelli et al. 2006), has increased to 26 the number of diaptomid species currently known to occur in Italy (Stoch 2006), and it confirms Italy as one of the European countries with the richest diaptomid copepod fauna (Dussart \& Defaye 2002). This finding is rather unexpected since no other species belonging to the Gigantodiaptomus subgenus have been reported south of the Alps and Pyrenées (see Marrone et al. 2010 for a review). The Italian finding further stresses the considerable cognitive gaps which affect our knowledge relating to particular taxa, even in the assumed betterknown countries in the west-Palaearctic area.

\section{ACKNOWLEDGEMENTS}

The authors of this paper wish to particularly acknowledge the valuable support of M. Korn (Senckenberg Natural History Collection, Dresden, Germany), who kindly provided Hemidiaptomus (G.) superbus specimens from Breitenhagen. We are also grateful to I. Ternjej (University of Zagreb, Croatia) and L. Samchyshina (Center of Megalopolis Ecomonitoring and Biodiversity Research NASU, Ukraine) for their stimulating discussions and for having provided important articles from the relevant literature. G. Rossetti (University of Parma, Italy) and F. Stoch (University of L'Aquila, Italy) kindly identified the ostracods and the cyclopoid copepods respectively. Finally, we recognise the contribution of Dr. A. Vistoli (Ufficio Ambiente e Sostenibilità, Comune di Ravenna) for having provided Permission to sample in the SIC ITA4070010 Pineta di Classe to DM. This study was supported by the University of Palermo, Italy (Fondi d'Ateneo, ex 60\%)

\section{REFERENCES}

Alfonso, G. \& G. Belmonte. 2011. Calanoida (Crustacea Copepoda) from the inland waters of Apulia (south eastern Italy). J. Limnol., 70(1): 57-68.

Alonso, M. 1996. Crustacea, Branchiopoda. In: Ramos, M.A. et al. (Eds), Fauna Iberica, vol. 7. Museo Nacional de Ciencias Naturales. CSIC. Madrid: 486 pp.

Alonso, M. 1998. Las lagunas de la Espaňa peninsular. Limnetica, 15: 1-176.

Beauchamp de, P. 1918. Notes faunistiques: quelques formes rares ou intèressantes de la region parisienne. Bulletin de la Société Zoologique de France, 43: 78-83.

Belousov, N.F. 1908. O vesennem izmenenii okraski u nekotoryh nashih rakoobraznyh (On spring color changes in some our crustaceans). Trudy Obstchestva Ispytatelej Prirody, 42: 3-45. (In Russian).

Błędzki, L.A. 2008. Widlonogi (Copepoda), Calanoida. In: Bogdanowicz, W. et al. (Eds), Fauna of Poland - characteristics and checklist of species. Muzeum i Instytut Zoologii PAN, Warszawa: 603 pp.

Borutzky, E.B., Stepanova, L.A. \& M.S. Kos. 1991. Opredelitel' Calanoida presnykh vod SSSR (Key to the freshwater calanoids of the URSS). Nauka, St. Petersburg: 504 pp. (In Russian).

Brehm, V. 1937. Süsswasserorganismen aus dem Elbursgebirge (Persien). Zoologischer Anzeiger, 118: 214-223.

Dussart, B. 1967. Les Copépodes des eaux continentales d'Europe occidentale. I. Calanoides et Harpacticoides. Ed. Boubée \& Cie, Paris: 500 pp.

Dussart, B. 1989. Crustacés copépodes calanö̈des des eaux intérieures africaines. Crustaceana, Supplement 15: 205 pp.

Dussart, B. \& D. Defaye. 2002. World Directory of Crustacea Copepoda of Inland Waters, I-Calaniformes. Backhuys Publishers, Leiden: $276 \mathrm{pp}$.

Einsle, U. 1993. Crustacea Copepoda. Calanoida und Cyclopoida. Süsswasserfauna Mitteleuropas, 8/4-1. Gustav Fisher Verlag: 206 pp.

Elster, H.J. 1931. Über einen Fundort von Diaptomus superbus Schmeil, nebst einigen Bemerkungen über die Farben der Copepoden. Zoologischer Anzeiger, 96: 145-251.

Gauthier, H. 1928. Recerches sur la faune des eaux continentales de l'Algérie et de la Tunisie. Imp. Minerva, Alger: $466 \mathrm{pp}$.

Gillandt, L. \& J.M. Martens. 1975. Wiederfund in Norddeutschland und Ergänzung der Veschreibung von Hemidiaptomus superbus (Schmeil, 1895) (Crust., Copepoda). Abhandlungen und Verhandlungen Naturwissenschaftichen Vereins in Hamburg, 18/19: 181-185

Gillandt, L., J.M. Martens \& H. Wilkens. 1983. Seltene Krebse temporärer Gewässer und ihre Verbreitung im Elbe-Bereich zwischen Schnackenburg und Hohnstorf (Crust., Anostraca, Notostraca, Copepoda). Abhandlungen und Verhandlungen Naturwissenschaftlichen Vereins in Hamburg, 25: 339-349.

Hall, T.A. 1999. BioEdit: a user-friendly biological sequence alignment editor and analysis program for Windows 95/98/NT. Nucleic Acids. Symposium Series, 41: 95-98.

Hamaidi, F., D. Defaye \& R. Semroud. 2010. Copepoda of Algerian fresh waters: checklist, new records, and comments on their biodiversità. Crustaceana, 83: 101-126.

Herbst, H. 1982. Deutsche existenzbedrohte Branchiopoda und Copepoda (Crustacea). Arch. Hydrobiol., 95: 107-114.

Jensen, S. 1905. Faunistik Fortegnelse over de danske Ferskvands-Copepoder. Videnskabelige Meddelelser Dansk naturhistorisk Forening i Kjøbenhavn, 6: 111-125.

Kiefer, F. 1932a. Versuch eines systems der Diaptomiden (Copepoda, Calanoida). Zoologische Jahrbücher, Abteilung für Systematik, Ökologie und Geographie der Tiere, 63: 451-520.

Kiefer F., 1932b. Versuch eines Systems der altweltlichen Diaptomiden (Copepoda, Calanoida). Zoologische Anzeiger, 100: 213-220.

Kiefer, F. 1978. Das Zooplankton der Binnengewaesser. Freilebende Copepoda. Die Binnengewässer, Band 26 Teil 2. E.Schweizerbart'sche Verlagbuchhandlung, Stuttgart: $343 \mathrm{pp}$.

Krmpotić, I. 1925. Beitrag zur Kenntnis der Entomostraken und Rotatorien, insbesondere der Diaptomiden Kroatiens und Slavoniens. Arch. Hydrobiol., 15: 5-69.

Löffler, H. 1961. Beiträge zur Kenntnis der Iranischen Binngewässer II. Regional-limnologische Studie mit besonderer Berucksichtigung der Crustaceenfauna. Int. Revue ges. Hydrobiol., 46: 309-406.

Margaritora, F.G. 1985. Cladocera. XXIII, Fauna d'Italia. Ed. Calderini, Bologna: 389 pp.

Marrone, F., R. Barone \& L. Naselli-Flores. 2006a. Ecological characterization and cladocerans, calanoid copepods and large branchiopods of temporary ponds in a Mediterranean island (Sicily, Southern Italy). Chemistry and Ecology, 22: 181-190.

Marrone, F., G. Castelli, R. Barone \& L. Naselli-Flores. 2006b. Ecology and distribution of Calanoid Copepods in 
Sicilian inland waters (Italy). Verh. int. Ver. Theor. Angew. Limnol., 29: 2150-2156.

Marrone, F., S. Lo Brutto \& M. Arculeo. 2010. Molecular evidence for the presence of cryptic evolutionary lineages in the freshwater copepod genus Hemidiaptomus G.O. Sars, 1903 (Calanoida, Diaptomidae). Hydrobiologia, 644: 115-125.

Meisch, C. 2000. Freshwater Ostracoda of Western and Central Europe. Spektrum Akademischer Verlag, Heidelberg, Berlin: $522 \mathrm{pp}$.

Minelli, A., S. Ruffo \& A. Vigna Taglianti. 2006. The Italian faunal provinces. In. S. Ruffo \& F. Stoch (Eds), Checklist and distribution of the Italian fauna. Memorie del Museo Civico di Storia Naturale di Verona - 2. serie - Sezione Scienze della Vita, 17: 37-39.

Mouelhi, S., G. Balvay \& M.M. Kraïem. 2000. Branchiopodes (Cténopodes et Anomopodes) et Copépodes des eaux continentales d'Afrique du Nord: inventaire et biodiversité. Zoosystema, 22: 731-748.

Rivas-Martinez, S. 1995. Classification bioclimatica de la tierra. Folia Batanica Matritensis, 16: 1-25.

Roy, J. 1924. Notes faunistiques sur les Copépodes de l'Afrique du Nord. Feuille des Naturalistes, 1: 101.

Roy, J. \& H. Gauthier. 1927. Sur les copépodes d'Algérie et de Tunisie. Bulletin de la Société zoologique de France, 52 : 558-575.

Ruffo, S. \& F. Stoch (Eds). 2006. Checklist and distribution of the Italian fauna. Memorie del Museo Civico di Storia Naturale di Verona, 2.serie, Sezione Scienze della Vita, 17: 301 pp., with CD-ROM.

Schmeil, O. 1895. Neue Spaltfusskrebse der Fauna der Provinz Sachsen. Zeitschrift für Naturwissenschaften, Halle, 68: 126-130.

Schmeil, O. 1896. Deutschlands freilebende Süsswasser-Copepoden. 3. Teil: Centropagidae. Bibliotheca Zoologica, Stuttgart, 21: 1-144.

Stepanova, L.A. 2005a. Species of the genus Gigantodiaptomus (Crustacea, Diaptomidae) in the Siberian fauna.
Zoologicheskii Zhurnal, 84: 313-320. (In Russian, with English abstract)

Stepanova, L.A. 2005b. Identification of Gigantodiaptomus and Occidodiaptomus (Crustacea, Diaptomidae) as independent genera. Zoologicheskii Zhurnal, 84: 754-760. (In Russian, with English abstract).

Stoch, F. 2006. Crustacea Copepoda Calanoida. In: Ruffo S., Stoch F. (Eds), Checklist and distribution of the Italian fauna. Memorie del Museo Civico di Storia Naturale di Verona - 2. Serie - Sezione Scienze della Vita, 17: 91-92.

Tamura, K., Dudley, J., Nei, \& S. Kumar. 2007. MEGA4: Molecular Evolutionary Genetics Analysis (MEGA) software version 4.0. Molecular Biology and Evolution, 24: 1596-1599.

Ternjej, I. \& I. Stankovic. 2007. Checklist of fresh and brackish water free-living copepods (Crustacea: Calanoida and Cyclopoida) from Croatia. Zootaxa, 1585: 45-57.

Thum, R.A. \& R.G. Harrison. 2009. Deep genetic divergences among morphologically similar and parapatric Skistodiaptomus (Copepoda: Calanoida: Diaptomidae) challenge the hypothesis of Pleistocene speciation. Biological Journal of the Linnean Society, 96: 150-165.

Tollinger, M.A. 1911. Die geographische Verbreitung der Diaptomiden und anderen Süss- und Brackwasser-Gattungen aus der Familie der Centropagiden. Zoologische Jahrbücher - Abteilung für Systematik, Geographie und Biologie der Tiere, 30: 302 pp.

Walter, T.C. 2010. Hemidiaptomus superbus (Schmeil, 1895). In: Walter T.C. \& Boxshall G. (Eds), World Copepoda database. Accessed through: Walter, T.C., Boxshall, G. (Eds) (2010). World Copepoda database at http://www.marinespecies.org/copepoda/aphia.php? $\mathrm{p}=\operatorname{taxd}$ etails\&id $=358767$ on $2010-10-27$.

Weisig, S. 1931. Diaptomus atropatenus sp. nov. mit einem Beitrag über die Diaptomidenfauna des östlichen Transkaukasiens. Zoologischer Anzeiger, 95: 255-262.

Received: October 2010

Accepted: December 2010 